\title{
EVOLUÇÃO VERSUS CRIAÇÃO: FALSO DILEMA
}

\section{EVOLUTION VERSUS CREATION: A FALSE DILEMMA}

\author{
João A. MacDowell*
}

\begin{abstract}
RESUMO - A evolução cósmica e biológica é hoje um fato universalmente admitido pela comunidade científica. Muitos julgam que essa posição científica é incompatível com a aceitação de um Deus criador do mundo, seja que neguem a criação em nome da evolução, seja que rejeitem a evolução em nome da fé. O artigo pretende apontar a inconsistência do dilema "evolução ou criação", mostrando, mediante uma reflexão filosófica, que ele deriva de uma falsa compreensão do método e do alcance tanto das ciências positivas como da teologia. Defende, além disso, que compete aos cientistas verificar se o neodarwinismo da teoria sintética é ou não uma explicação científica satisfatória dos fenômenos. Afirma, porém, que também essa teoria seria compatível com uma ideia adequada de criação, mesmo que não recorra, para explicar a evolução, nem à intervenção de uma causa eficiente transempírica, nem a uma inteligência superior que oriente o processo evolutivo para determinados fins. Com efeito, a ação criadora de Deus que confere o ser e agir a toda a realidade natural e a orienta, de algum modo, para seus fins, tem um caráter transcendente, e, por princípio, não pode ser detectada pela investigação científica, mas, tão somente, pela reflexão filosófica.
\end{abstract}

PALAVRAS-CHAVE - Evolução. Criação. Neodarwinismo. Método científico. Reflexão filosófica.

ABSTRACT - Cosmic and biological evolution is universally accepted by the scientific community today. Many people, however, believe that this scientific position is irreconcilable with the idea of a worldcreator God; they either deny creation in virtue of evolution or reject evolution in virtue of their faith. This paper does not intend to prove God's existence. Its purpose is to show the fallacy of the evolution/ creation dilemma and to explain by means of philosophical reflection that this dilemma arises from a false understanding of the respective

* Professor do Departamento de Filosofia da Faculdade Jesuíta de Filosofia e Teologia (FAJE/ BH) e Coordenador do Programa de Mestrado em Filosofia do mesmo Departamento.

\begin{tabular}{|l|l|l|l|l|l|}
\hline Veritas & Porto Alegre & v. 56 & n. 2 & maio/ago. 2011 & p. 84-120 \\
\hline
\end{tabular}


methods and purviews of the positive sciences and theology. Moreover, the paper maintains that it falls to scientific research to establish whether the neo-darwinian theory of evolution provides a satisfactory explanation of the phenomena or not. It claims nevertheless that such a theory, should it be definitively confirmed, could also be compatible with an appropriate understanding of creation, even if its explanation of evolution does not appeal to the intervention of an efficient transempirical cause nor to a higher intelligence which would guide the evolutionary process towards its goals. In fact, if God exists, then God's creative action, which gives being and act to the whole natural reality and guides it towards its ultimate ends, has a transcendent character and by no means can it be detected by scientific research, but only by philosophical thinking.

KEYWORDS - Evolution. Creation. Neo-darwinism. Scientific method. Philosophical reflection.

\section{Introdução}

O segundo centenário do nascimento de Charles Darwin em 2009, que coincidiu com os 150 anos da publicação de sua célebre obra "On the Origin of Species by means of natural selection", renovou também no Brasil o debate sobre a teoria da evolução. Não se trata apenas de discussões científicas sobre o fato da evolução das espécies biológicas ou sobre os mecanismos que a poderiam explicar. O que atiça os ânimos, nesse contexto, é, sobretudo, a questão da compatibilidade entre evolução e criação, entre a aceitação da teoria da evolução e a aceitação da criação do universo e da vida por Deus. A tensão se estabelece, assim, entre uma visão religiosa ou cristã e uma visão agnóstica ou atéia da existência.

Em contraste com essa abordagem polêmica da problemática da evolução, propomos a seguinte tese fundamental: não há contradição entre a aceitação da ideia científica da evolução e a afirmação da criação do universo e da vida por Deus.

Como veremos, a reflexão teológica pode mostrar que a ideia cristã da criação por Deus não é incompatível com a teoria científica da evolução. No entanto, a teologia, como tal, enquanto se funda na fé, não pode oferecer uma solução ao dilema "evolução ou criação". A discussão desse problema, numa perspectiva puramente racional, compete propriamente à filosofia. E é na perspectiva filosófica que o tema será abordado neste artigo. Nele, procuraremos demonstrar que a oposição entre evolução e criação é um falso dilema. Com efeito, uma vez que o problema da existência de Deus e da criação do mundo, por escapar à verificação experimental, não pertence ao âmbito das ciências positivas, como a biologia, não pode ser resolvido por elas. É um problema de caráter 
filosófico. Por isso, uma teoria científica, como a teoria da evolução, em princípio, não pode implicar nem a afirmação nem a negação de um Deus criador do mundo.

Esta tese parece, à primeira vista, ousada, insustentável. Com efeito, se voltarmos nosso olhar para a história dos tempos modernos, verificaremos que foram frequentes, para não dizer contínuos, os conflitos entre a visão cristã do mundo e a ciência. Baste lembrar a questão de Galileu e a condenação pela Igreja do heliocentrismo que ele defendia. O outro grande pomo de discórdia entre a fé e a razão moderna foi justamente a questão da evolução. Desde a publicação da obra de Darwin, a sua teoria, por um lado, tem provocado a rejeição de Deus por parte de muitos de seus adeptos e, por outro, tem sido rechaçada como incompatível com a fé por muitos cristãos.

A incompatibilidade entre criação e evolução pode ser afirmada a partir de dois pontos de vista opostos, o criacionismo e o evolucionismo, empregando esses termos em um significado peculiar, que será logo definido. Trata-se assim do conflito entre:

- o criacionismo, enquanto negação da evolução em nome da fé em Deus Criador

- e o evolucionismo, enquanto negação do Deus Criador em nome da teoria da evolução. ${ }^{1}$

\section{A teoria da evolução}

Antes, porém, de detalhar as posições desses dois partidos adversários, faz-se mister apresentar brevemente a noção científica de evolução. A evolução biológica, objeto dos estudos de Darwin, inserese hoje na concepção global da evolução cósmica. Essa perspectiva só começou a delinear-se com certa clareza a partir da década de 20 do século passado com as primeiras formulações da Teoria do Big-Bang. Trata-se da afirmação de que o universo não existiu sempre no seu estado atual, antes se foi constituindo progressivamente, ao longo de cerca de 13,7 bilhões de anos, a partir de uma realidade física originária absolutamente indiferenciada.

1 O termo "evolucionismo" significou originalmente, no século 19, a simples afirmação e defesa da teoria da evolução biológica. Na verdade, hoje em dia, ele praticamente não é usado nos meios científicos, já que essa teoria é consensual entre os especialistas. Assumimos, porém, o termo no significado especial, descrito no texto, referindo-nos a uma posição, que consideramos não-científica, mas que é largamente adotada por cientistas, ou seja, a ideia de que a aceitação da teoria biológica da evolução exclui a afirmação de Deus e da criação do mundo. Trata-se, portanto, do evolucionismo ateu. 
Em princípio, pode-se tentar explicar cientificamente a origem dos seres vivos de dois modos básicos. Por um lado, pelo fixismo, segundo o qual as espécies de organismos atuais permanecem inalteradas desde que surgiram na Terra. Esta posição hoje abandonada contrapõe-se à teoria da evolução biológica, formulada no contexto da evolução cósmica e geológica. Em uma primeira aproximação, podemos caracterizar a evolução biológica como a afirmação de que as espécies de organismos atualmente existentes surgiram na Terra a partir de outras espécies de organismos que foram se diferenciando ao longo do tempo ${ }^{2}$.

Tomada em sentido pleno, a evolução biológica implica que todos os organismos vivos descendem de uma mesma espécie originária de organismos muito simples. Supõe, portanto, um único tronco comum, a partir do qual foram se diversificando novos tipos de organismos em sucessivas transformações até o surgimento das espécies atuais, que, em princípio, seguem evoluindo. Nessa perspectiva, o mundo da vida pode ser comparado a uma árvore cujos ramos vão se multiplicando e diferenciando cada vez mais ao longo do tempo a partir do tronco comum.

\subsection{Fato da evolução}

O próprio processo de evolução do universo manifesta uma tendência da matéria para a auto-organização, passando dos núcleos atômicos, aos átomos e desses a moléculas sempre mais complexas, até os ácidos nucléicos, como o ácido desoxirribonucléico (DNA) e o ácido ribonucléico (RNA), que apresentam uma nova característica: a capacidade de replicação e memória, pela qual a mesma estrutura se reproduz ${ }^{3}$. Mas, fala-se propriamente de vida quando o material genético é individualizado mediante a constituição de uma membrana que envolve o citoplasma, constituindo a célula orgânica ${ }^{4}$. Esse fato ocorreu na Terra há cerca de 3,7 bilhões de anos.

2 A espécie, composta por organismos individuais, corresponde ao nível inferior da classificação biológica. Não há definição precisa de espécie biológica. Do ponto de vista fenotípico, trata-se de um grupo de indivíduos orgânicos que têm características comuns e (normalmente) são capazes de acasalamento para a procriação gerando descendentes férteis. Do ponto de vista genotípico, trata-se de uma população de organismos com um alto índice de semelhança genética.

3 Fala-se de memória biológica se o estado de um sistema biológico depende de sua história passada, além das condições presentes. Esta memória é genética se é recordada no material genético e estavelmente herdada pela divisão celular.

4 O organismo vivo implica a individuação, com a distinção clara entre interior e exterior. As suas características básicas são: (1) composto de uma ou mais células (vírus não são células, mas parasitas de células); (2) capacidade de desenvolver-se e reproduzirse; (3) capacidade de obter e utilizar energia; (4) capacidade de reagir e adaptar-se ao ambiente. 
A partir daí, as etapas da evolução da vida são descritas grosso modo da seguinte maneira pela biologia atual. Os organismos unicelulares mais simples, cuja célula não possui um núcleo, são classificados como procariotas, incluindo dois domínios: Bacteria e Archaea. Um passo adiante no processo evolutivo corresponde ao surgimento do terceiro domínio, constituído pelos eucariotas (Eukarya), organismos unicelulares ou pluricelulares, cujas células são dotadas de núcleo. ${ }^{5}$ Todas as formas mais complexas de vida passam por esse ramo do processo evolutivo, que abrange quatro reinos de organismos: 6 Protistae (protistas, por exemplo, amebas), Fungi (fungos, por exemplo, cogumelos, mofos), Plantae (plantas) e Animalia (animais) ${ }^{7}$.

O agrupamento de células em uma unidade superior, isto é, em um organismo pluricelular, constitui um novo avanço no processo de autoorganização da matéria. Desse modo, as células vão se especializando nas suas funções, constituindo vários tipos de tecidos celulares. Alguns protistas, como algumas espécies de algas, e todos os outros eucariotas são organismos pluricelulares. Outro marco decisivo na história da vida é a reprodução sexuada, resultante da fusão de dois gametas, originários de organismos pluricelulares sexualmente diferenciados. Ela ocorre na imensa maioria das espécies animais e em grande parte das plantas.

$\mathrm{Na}$ evolução dos animais é fundamental a diferenciação entre invertebrados (insetos, crustáceos, vermes, moluscos, etc.) e vertebrados. A vertebralização implica a emergência da coluna vertebral e do crânio, como proteção do sistema nervoso central. Entre os vertebrados um novo patamar da evolução é alcançado com a homotermia, isto é, a manutenção de uma temperatura corporal constante e independente do meio ambiente, que distingue as aves e os mamíferos (sangue quente) dos répteis, anfíbios e peixes. Com a gestação intrauterina e a lactação, uma classe particular de vertebrados - os mamíferos - passou a oferecer

5 O núcleo contém o material genético da célula, envolvido por uma membrana.

6 C. Woese, em 1977, distinguiu os Archaea das Bacteria, contestando a divisão então vigente dos organismos em apenas dois grupos básicos: procariotas e eucariotas. A classificação em três domínios é hoje universalmente aceita, bem como a divisão dos Eucarya em quatro reinos, como exposto no texto.

7 Os animais, definidos como metazoários, isto é, organismos pluricelulares, possuem ainda as seguintes características: (1) são eucariotas; (2) são heterotróficos (ao contrário dos vegetais e outros organismos, alimentam-se de matérias orgânicas); (3) não possuem parede celular em volta da membrana celular (ao contrário dos vegetais e outros organismos); (4) são em geral capazes de mover-se por própria iniciativa; (5) a evolução de seu embrião inclui o estágio de blástula; (6) possuem órgãos sensoriais especializados para reconhecer e responder aos estímulos do ambiente. 
maior proteção à sua descendência. O próximo passo, que surge entre os mamíferos, é a bipedia, que libera a mão da função locomotora e o crânio em relação à face, permitindo o seu maior desenvolvimento, que fornecerá as condições para a emergência da reflexão e da linguagem articulada na espécie humana.

As investigações da paleontologia, que revelam através da determinação da idade dos restos fósseis a crescente complexificação e diferenciação morfológica dos fenótipos das várias linhagens de espécies orgânicas, serviram durante muito tempo como esteio básico da ideia da evolução biológica. Hoje em dia, a análise do genoma dos organismos oferece a confirmação e o detalhamento do parentesco entre todos os seres vivos originários de um tronco comum mediante sucessivas ramificações. Certamente, são ainda muitas as passagens não bem esclarecidas - "elos perdidos" (missing links) - na continuidade desse processo evolutivo, bem como os enigmas diante de certas alternativas assumidas pela linha da vida no curso do tempo. Não obstante essas obscuridades, o fato da evolução das espécies desde as formas mais primitivas de organismos unicelulares até o Homo sapiens é hoje geralmente admitido pela comunidade científica. O próprio Papa João Paulo II, em alocução aos membros da Academia Pontifícia de Ciências (1996), reconheceu que a evolução hoje é mais do que uma mera hipótese.

\subsection{Teorias explicativas da evolução}

Se a afirmação da evolução é quase unânime entre os entendidos no assunto, o mesmo não acontece com as tentativas de explicá-la cientificamente. A primeira teoria da evolução foi apresentada pelo biólogo francês Lamarck, no início do século 20. O lamarckismo, que constitui, aliás, uma simplificação das suas ideias, atribui a evolução à transmissão hereditária de caracteres morfológicos adquiridos em virtude do uso ou desuso de certos órgãos em função das necessidades vitais do ser vivo.

Essa explicação foi abandonada após a publicação da obra de Darwin. Para este, a evolução das espécies se deve à seleção natural, que privilegia os indivíduos, que se adaptam melhor ao ambiente e que deixam um maior número de descendentes, de modo que o grupo resultante de sua reprodução se diferencia progressivamente do grupo original até constituir uma nova espécie. Darwin reconhece que a seleção natural não explica as diferenças iniciais entre os indivíduos, que levam alguns a adaptar-se ao seu ambiente e outros não. Insiste, porém, na ideia de que o ambiente atua seletivamente sobre eles, reduzindo o número dos mal-adaptados e aumentando o número dos que conseguem sobreviver às mudanças ambientais. 


\subsection{Teoria sintética da evolução}

A lacuna básica do darwinismo foi suprida muitas décadas depois, pela redescoberta das leis da genética de $\mathrm{Mendel}^{8}$, bem como pela identificação dos genes, como elementos da estrutura celular ${ }^{9}$, e de suas mutações ${ }^{10}$. Surge, assim, a teoria sintética ou neodarwinismo, que explica a diferenciação das espécies pela conjugação de dois fatores básicos, as mutações genéticas e a seleção natural. Das mutações genéticas resultam novas características fenotípicas, que diferenciam os indivíduos de uma mesma população, de modo que eles passam a adaptar-se em graus diversos ao meio ambiente. Nessa perspectiva, é possível formular uma definição genética da evolução, como a soma total das mudanças herdadas geneticamente nos indivíduos que partilham o "banco" (pool) de genes de uma população. Em outras palavras, trata-se

8 Gregor Mendel, sacerdote católico agostiniano, foi o fundador da Genética, a partir de experimentos realizados por volta de 1860. Ele estabeleceu que: (1) cada traço manifesto de um organismo (fenótipo) é determinado por um fator próprio (gene) herdado dos pais; (2) este fator é constituído por dois elementos constantes na espécie (alelos), herdados um de cada pai, e em cada indivíduo podem ser idênticos (homozigoto) ou distintos (heterozigoto); (3) um desses elementos é dominante e o outro recessivo, ou seja, não se manifesta quando o outro é distinto; (4) por conseguinte, um traço não manifesto em um indivíduo pode ser transmitido aos descendentes. Os termos entre parênteses são posteriores a Mendel.

9 A articulação das leis da hereditariedade com a estrutura celular (genes, cromossomos, etc.) e a descoberta das mutações genéticas como fator decisivo da evolução das espécies devem-se, sobretudo, às investigações do norte-americano Thomas H. Morgan e seus colaboradores, a partir do início do século 20. Do ponto de vista biomolecular, um gene é um segmento (sequência específica de ácidos nucléicos) de um cromossomo ao qual corresponde um código específico, isto é, uma informação para produzir determinada proteína e assim definir uma característica do organismo. Cromossomo é uma estrutura de DNA e proteínas, localizada no núcleo das células dos eucariotas. Cada cromossomo contém uma única molécula de DNA, extremamente longa, formada de duas cadeias de nucleotídeos unidas em forma de espiral helicoidal. Cada célula corporal (diplóide), resultante nos organismos sexuados da fusão de duas células germinais (haplóides), esperma e óvulo, contém dois conjuntos de cromossomos, sendo cada um desses conjuntos formado pelos alelos de todos os genes característicos do organismo respectivo. O genoma é o conteúdo genético total de um organismo integrado em um ou mais cromossomos. As células humanas contêm 46 cromossomos, com milhares de genes (cerca de 20 a 25 mil).

10 Mutações são mudanças nos genes, que podem provocar uma alteração no padrão normal (alelo prevalente) da população. Considera-se que o padrão normal é alterado quando a mutação atinge menos de $1 \%$ da população. Caso contrário, fala-se de polimorfismo. Trata-se de mudanças hereditárias que atingem as células germinais, ao contrário das mutações nas células somáticas, que podem transmitir-se pela multiplicação destas células no mesmo organismo, mas não passam aos descendentes. As mutações podem ser causadas p.ex. por radiações ultravioleta, drogas químicas, vírus, e também por alterações internas do próprio organismo. 
da mudança na frequência de determinados alelos no banco de genes de uma população.

As pesquisas mais recentes obrigaram a introduzir várias modificações na compreensão neodarwiniana dos mecanismos da evolução. Tratase, em particular, de outros fatores que determinam a evolução, independentemente da seleção natural. É o caso da chamada deslocação genética, que ocorre em populações relativamente reduzidas, nas quais as leis da probabilidade para grandes números não se verificam. É assim, através da descendência de um pequeno grupo de ancestrais, que se explica a predominância do sangue tipo $O$ entre os indígenas da América Central e do Sul. Também a transferência genética em função da imigração pode alterar a frequência de determinados alelos numa população. Por exemplos, os filhos de soldados norte-americanos com mulheres vietnamitas, durante a Guerra do Vietnam, alteraram as frequências no banco de genes da população do país.

Entretanto, a correção mais significativa da teoria sintética refere-se à explicação do mecanismo da evolução, mediante alterações morfológicas mínimas, que vão se acentuando cumulativamente ao longo de grandes períodos de tempo. Embora essas transições lentas e progressivas sejam constatadas, elas dificilmente explicam os momentos cruciais do processo evolutivo. De fato, as observações atuais levam a crer que em vez de uma linha ascensional contínua, a evolução acontece por mudanças bruscas que ocorrem em determinados períodos seguidos de outros de relativa estabilidade da espécie. Nessa perspectiva, a seleção natural resulta, sobretudo, de mudanças radicais do ambiente provocadas por alterações climáticas correspondentes aos períodos glaciais, bem como por catástrofes resultantes, por exemplo, do choque de meteoritos ou de uma fase de violentas erupções vulcânicas.

Se o próprio fato da evolução apresenta as suas obscuridades, mais ainda a sua explicação pela teoria sintética. No entanto, com as ressalvas acima feitas, ela é a posição claramente predominante nos meios científicos. Com efeito, embora os mecanismos da evolução ainda apresentem vários mistérios, é inegável que a origem de novas espécies depende seja da influência do meio ambiente (seleção natural), seja das alterações do patrimônio genético. Cada espécie tem seu patrimônio genético próprio. Ao contrário, o código genético é o mesmo para todos os seres vivos existentes, de todas as espécies. Trata-se do conjunto de regras pelas quais a informação codificada no material genético é traduzida em proteínas (sequências de amino-ácidos) pelas células vivas. Esse é um dos argumentos mais fortes para a afirmação de que todos os seres vivos da Terra descendem de uma única população original. 
A teoria sintética contrapõe-se às teorias que consideram a evolução cientificamente inexplicável sem a admissão de um finalismo inscrito na própria natureza, que a orienta no sentido de uma crescente complexidade e aperfeiçoamento das espécies de organismos. Entretanto, ela não exclui a existência de uma finalidade nos seres vivos. Em muitos de seus órgãos esta finalidade é evidente. Por exemplo, o olho humano serve para ver ${ }^{11}$. Além disso, ela não entende a evolução como fruto do acaso, já que, para a ciência, todo fenômeno tem sua ou suas causas. Nem por isso, nessa concepção, o efeito global da ação das causas naturais pode ser previamente percebido, como se estivesse nelas predeterminado. Nesse sentido, a oposição determinismo causal versus acaso é substituída pela distinção entre previsível e imprevisível. Por um lado, o aleatório das interações entre os elementos de um sistema não se opõe ao determinismo das leis estatísticas (grande número). Por outro, a determinação de um sistema não implica a previsibilidade, como decorre da teoria do caos $^{12}$.

À luz dessas considerações, a teoria sintética admite que a evolução é um processo inteiramente imprevisível. A posteriori, por uma visão retrospectiva ${ }_{\perp}$ pode-se explicar, em princípio, por que ela aconteceu de tal maneira. Mas, ao contrário do que postulam as teorias finalistas, não se pode detectar a priori o que acontecerá no futuro, ou seja, dos elementos presentes no início do processo ou em qualquer ponto de sua trajetória podem surgir diferentes resultados. Por exemplo, considerando as condições iniciais do cosmo não se pode prever que a evolução culminaria no ser humano. Trata-se da essencial contingência dos processos da natureza ${ }^{13}$. Todavia, as possibilidades de diferentes trajetórias do processo evolutivo não são infinitas. São condicionadas pelas determinações reais do sistema cósmico em cada momento. Entretanto, este condicionamento não determina estritamente o futuro, mas apenas o limite das possibilidades efetivas.

${ }_{11}$ Como diremos mais adiante, não se trata aqui de finalidade no sentido propriamente filosófico e metafísico do termo, mas antes de funcionalidade.

12 Segundo essa teoria, diferenças mínimas nas condições iniciais de dois sistemas dinâmicos podem levar a enormes diferenças na sua evolução e no seu estado final, mesmo em um intervalo de tempo relativamente breve. Isso acontece, embora se trate de sistemas determinísticos, de modo que a sua trajetória futura está plenamente determinada em suas condições iniciais, sem intervenção de elementos aleatórios. Por outro lado, um sistema artificial, cujas condições iniciais são fixadas aleatoriamente (tirando a sorte) pode evoluir para uma estrutura ordenada, estável ou circular.

13 Essa característica tem sido acentuada pelo paleontólogo contemporâneo Steven J. Gould, ao qual também se deve a ideia, acima mencionada, da alternância entre períodos de transformações bruscas e períodos de relativa estabilidade na história da vida. 
Em concreto, de acordo com a teoria sintética, a imprevisíbilidade da evolução resulta de que um de seus fatores essenciais, as mutações genéticas, é aleatório. De fato, elas não obedecem a uma lei específica, mas podem acontecer a qualquer momento em função de inúmeras circunstâncias. Pelo contrário, a seleção natural, que exerce um crivo sobre as mutações tem um caráter determinístico, enquanto as configurações do organismo, que surgem das mutações, são efetivamente mais ou menos favoráveis à sua sobrevivência em um determinado ambiente. Esse ambiente pode, porém, variar com o tempo, o que confere novamente um caráter imprevisível à evolução. Não obstante essa imprevisibilidade de sua trajetória, a evolução como tal é necessária, já que os seres vivos estão sujeitos permanentemente a um fluxo de acontecimentos capazes de transformá-los. Entretanto, a resposta do organismo a essas influências exteriores não pode ser atribuída a elas. A ação dos fatores ambientais não cria a mudança; ela não é senão a ocasião para o sistema orgânico realizar as suas diferentes potencialidades.

\subsection{Teorias finalísticas da evolução}

Em contraste com o Neodarwinismo, as teorias finalísticas da evolução, nas suas várias formas, apelam para um plano da inteligência criadora, que orienta para o mais alto todo o processo evolutivo. Tal é, por exemplo, a visão grandiosa que traça Teilhard de Chardin da evolução criadora. Ele descobre uma convergência profunda entre os dados científicos e o cristocentrismo do Novo Testamento, mostrando que a flecha da evolução aponta, mais além do âmbito biológico, para o ponto Ômega, no qual se dará a comunhão definitiva de todo o universo criado com o seu Criador.

Em uma perspectiva estritamente científica, as recentes teorias do planejamento inteligente (intelligent design) insistem no caráter absolutamente improvável da trajetória da evolução, tanto no seu conjunto, como em muitos dos passos dados efetivamente ao longo do processo evolutivo. Daí a conclusão que a única explicação racionalmente satisfatória desses fenômenos é o recurso a um direcionamento da natureza para determinado fim, o que só pode acontecer por uma inteligência imaterial e superior ao mundo empírico ${ }^{14}$. Os partidários desta teoria recorrem, por exemplo, à "complexidade irredutível" da

14 Se a explicação alternativa da evolução pela teoria sintética é ou não satisfatória é uma questão que deve ser resolvida cientificamente. Mas, se ela não for satisfatória, a ciência só poderá afirmar que o processo evolutivo permanece inexplicável. Apelar para uma causa trans-empírica, como fazem os defensores do planejamento inteligente, poderá ser válido. Mas, não será uma posição científica, como pensam, mas filosófica, como veremos mais adiante. 
célula viva. Argumentam que a origem da vida, enquanto sistema funcional integrado, depende do aparecimento simultâneo de uma série de fatores, cuja conjunção se torna inexplicável sem um planejamento inteligente. Com efeito, à extrema improbabilidade das mutações que originam os componentes da célula, acresce o fato de que a emergência de cada um deles depende de todos os outros e a falta de qualquer um deles torna inviável a vida orgânica ${ }^{15}$. Essa circunstância aumenta exponencialmente a improbabilidade do efeito, ou seja, do surgimento da célula viva.

\section{Posições conflitivas}

Uma vez apresentado sumariamente o panorama atual a respeito da questão científica da evolução das espécies, podemos voltar ao nosso ponto inicial, a relação entre evolução e criação. A afirmação da incompatibilidade entre essas duas ideias constitui o denominador comum de duas posições extremas:

- a negação da evolução em nome da criação, que denominamos criacionismo;

- a negação da criação em nome da evolução, que denominamos evolucionismo.

\subsection{Criacionismo}

O termo "criacionismo" poderia designar simplesmente a ideia, própria da teologia e da filosofia cristã, de que o mundo é criado por Deus. Aqui, porém, ele assume o significado mais explícito, que recebeu no século 20, de negação da evolução como incompatível com a criação, ou seja, de explicação da origem da vida e das espécies biológicas por uma intervenção criadora de Deus, alterando o curso da natureza, e não pela evolução natural do universo material. Trata-se, na verdade, de uma afirmação teológica ou filosófica, que, como veremos, baseia-se em uma noção inadequada de criação e assume, frequentemente, um cunho político-ideológico.

\subsubsection{Histórico}

Neste sentido, o criacionismo nasceu nos EUA por volta de 1920 como um movimento religioso que chegou a obter a proibição do ensino da teoria

15 Os principais representantes dessa corrente são o biólogo norte-americano Michael Drehe (Darwin`s Black Box. The Biochemical Challenge to Evolution, New York: The Free Press, 1996 [A caixa preta de Darwin, Rio de Janeiro: Zahar, 1997]) e o matemático William Dembski (Intelligent Design. The Bridge between Science and Theology, Downers Grove, Ill: InterVarsity Press, 1999). 
da evolução nas escolas públicas de vários Estados norte-americanos. A oposição dos criacionistas à teoria da evolução era motivada acima de tudo pela rejeição da ideia do ser humano como simples descendente de animais e, portanto, destituído de valores morais (primeiro "processo do macaco": Tennessee, 1925).

O movimento ressurgiu nas décadas de 60 a 80, sob a forma de um "criacionismo científico", que, embora partindo de motivações religiosas e éticas, procurava justificar a sua recusa da evolução com argumentos científicos: a evolução não é um fato comprovado, mas uma hipótese, que apresenta muitos pontos obscuros, extremamente improváveis, cientificamente duvidosos e que, portanto, não merece crédito. A controvérsia levou a batalhas judiciais, envolvendo líderes políticos e o próprio Presidente Reagan, sobre a constitucionalidade de leis de vários Estados americanos, que permitiam ou rejeitavam o ensino do criacionismo nas aulas de biologia das escolas públicas. Foram variados os pronunciamentos da justiça dos vários Estados e da própria Suprema Corte, ora proibindo o ensino tanto do criacionismo como da evolução, ora permitindo ou prescrevendo o ensino de ambas as concepções.

Novas disputas científicas e judiciais surgiram nos últimos anos (governo do Presidente Bush) provocadas, sobretudo, pelo "movimento do planejamento inteligente", que admite a evolução, mas afirma que ela só pode ser entendida se orientada por uma inteligência divina. Com efeito, segundo esta posição, certos aspectos do universo e dos seres vivos são mais bem explicados por uma causa inteligente do que por processos não direcionados como a seleção natural.

A força do criacionismo nos EUA pode ser aquilatada pela resposta a uma sondagem realizada em 2008. À pergunta "Os seres humanos, como os conhecemos hoje, desenvolveram-se a partir de espécies mais antigas de animais?", 40\% responderam "sim", 40\%, não, e 20\% "não sei"16.

\subsubsection{Formas de criacionismo}

\section{(a) Criacionismo radical (Young Earth Creationism)}

Trata-se de uma forma de fundamentalismo cristão, baseada na interpretação literal da Bíblia. A Terra foi criada por Deus em seis dias da maneira narrada no livro do Gênese. A sua idade, calculada em base

16 Bem diferentes são as respostas à mesma sondagem nos países europeus:

França: Sim: 80\%/Não: 14\%/Não sei: 06\% Alemanha: Sim: 74\%/Não: 22\%/Não sei: 04\% Itália: Sim: 72\%/Não: 20\%/Não sei: 08\% Grécia: Sim: 52\%/Não: 34\%/Não sei: 14\% Turquia: Sim: 26\%/Não: $52 \%$ / Não sei: $22 \%$. 
às genealogias bíblicas, é de apenas 6.000 anos (ou, segundo outros, 10.000). Adotando o fixismo, afirma que as plantas e os animais, hoje existentes, foram criados diretamente por Deus "segundo as suas espécies", respectivamente no terceiro, quinto e sexto dias (cf. Gn 1.11-25). Admitem, portanto, que os seres humanos conviveram, por exemplo, com os dinossauros, destruídos pelo dilúvio bíblico.

\section{(b) Criacionismo moderado (Old Earth Creationism)}

Corresponde a várias posições que rejeitam uma leitura estritamente literal da Bíblia, aceitando os dados da astronomia e da geologia quanto à idade do universo e da Terra. Alguns admitem apenas a micro-evolução no interior da espécie ou pouco além. Outros aceitam até certo ponto a origem comum das espécies biológicas (árvore filogenética da vida), mas com exceções importantes, especialmente quanto à origem da vida e do homem (a partir de outros primatas), resultante de uma intervenção direta de Deus.

(c) Movimento do Planejamento Inteligente (Intelligent Design Movement)

Esse movimento de inspiração religiosa não se identifica com o criacionismo no sentido estrito, já que admite a evolução do universo e das espécies biológicas. Baseia-se, como vimos anteriormente, em dados científicos comprovados, para tentar refutar o neodarwinismo, concluindo que a evolução não pode ser totalmente explicada senão como resultado do planejamento de uma inteligência criadora. Nessa perspectiva, a evolução torna-se um argumento para provar a existência de Deus.

\subsection{Evolucionismo}

No sentido aqui definido, o evolucionismo consiste na negação da criação e da existência de Deus em nome da evolução. Embora pretenda basear-se nela, não se confunde com a teoria científica da evolução. Corresponde, antes, a uma posição filosófica ou ideológica, que, como veremos, além de desconhecer os limites do método científico e a natureza da argumentação filosófica, utiliza uma ideia filosófica e teologicamente inaceitável de Deus e de criação. Essas carências epistemológicas são, porém, muito comuns hoje em dia, de modo que muitos cientistas e pessoas influenciadas pela mentalidade científica e pelo prestígio da ciência aderem a esse evolucionismo.

\subsubsection{O evolucionismo de Richard Dawkins}

Tomamos Richard Dawkins como paradigma do evolucionismo, porque com o seu livro "Deus - um Delírio", publicado em 
$2006^{17}$, ele se tornou em nossos dias um dos principais protagonistas dessa posição de combate contra a ideia de Deus e da criação em nome da evolução ${ }^{18}$.

Biólogo inglês, cientista respeitado, professor da Universidade de Oxford, Dawkins destacou-se como publicista com o livro "O Gene Egoísta", publicado em $1976^{19}$, no qual com grande competência e com um estilo vivo e acessível, apresenta e justifica a evolução das espécies à luz da teoria neodarwinista. Apoiado no seu prestígio científico e no seu êxito como escritor, ele abandona pouco a pouco o campo da divulgação científica séria, para enveredar na polêmica anti-religiosa ${ }^{20}$.

Essa tendência culmina em "Deus - um Delírio", como se pode ver pela apresentação que é feita da obra, em uma resenha inteiramente favorável: "O objetivo deste texto mordaz é provocar; provocar os religiosos convictos, mas principalmente provocar os que são religiosos 'por inércia', levando-os a pensar racionalmente e trocar sua 'crença' pelo 'orgulho ateu' e pela ciência. Dawkins despreza a ideia de que a religião mereça respeito especial, mesmo se moderada [...]. O biólogo usa seu conceito de memes (ideias que agem como os genes) e o darwinismo para propor explicações à tendência da humanidade de acreditar num ser superior. E desmonta um a um, com base na teoria das probabilidades, os argumentos que defendem a existência de Deus [...]"21.

Trata-se, portanto, de um panfleto, que, ultrapassando os limites do método científico, aborda questões filosóficas e teológicas, sem conhecimento de causa, caindo em grosseiros mal-entendidos e utilizando raciocínios destorcidos em sua argumentação contra a existência de Deus e a religião ${ }^{22}$. Não é nosso objetivo, aqui, contestar todos esses argumentos. Interessa-nos apenas citá-lo como paradigma do evolucionismo, ou seja, expor sua crítica da existência de Deus a partir da ideia de evolução.

17 São Paulo: Companhia de Letras, 2007 [The God Delusion, Boston/New York: Houghton Mifflin Company, 2006].

18 Outro propagandista contemporâneo do ateísmo a partir da evolução é o filósofo norteamericano Daniel C. Dennet, especialmente nas obras Darwin `s Dangerous Idea: Evolution and the Meaning of Life, New York: Simons \& Schuster, 1995, e Breaking the Spell, 2006 [Quebrando o Encanto. A religião como fenômeno natural, São Paulo: Globo, 2006].

19 The Selfish Gene, New York / Oxford: Oxford Univ. Press, ${ }^{3} 2006$.

20 Referimo-nos a obras como por exemplo O relojoeiro cego [The Blind Watchmaker] e Escalando o Monte Improvável [Climbing Mount Improbable].

21 Sinopse da "Livraria Cultura": www.livrariacultura.com.br, acessada em outubro 2009.

22 É o que constata um critico sério e competente: "One of the most melancholic aspects of The God Delusion is how its author appears to have made the transition from a scientist with a passionate concern for truth to a crude antireligious propagandist who shows a disregard for evidence." (Alister McGrath, The Dawkins Delusion. Atheist Fundamentalism and the Denial of the Divine, London: SPCK, 2007, p. 27). 


\subsubsection{Argumento evolucionista contra a existência de Deus}

A argumentação de Dawkins pode ser articulada em dois passos: Deus não é necessário, nem possível ${ }^{23}$.

\section{(a) Deus não é necessário}

Com os adeptos da teoria sintética, Dawkins admite que os organismos vivos, por exemplo, o olho humano, uma asa, uma aranha, etc., apresentam uma complexidade admirável, uma organização finalística (design), que tem uma probabilidade mínima de surgir na natureza ${ }^{24}$. Daí a tendência espontânea a atribuir a sua existência a um ser inteligente, o Criador, entendido por analogia com o engenheiro que planeja e constrói um aparelho com determinada finalidade ${ }^{25}$. Entretanto, essa interpretação é falsa, pensa Dawkins. Não é necessário recorrer a Deus porque a ciência por meio da seleção natural explica plenamente o processo evolutivo do qual resultaram tais organismos.

Nesse sentido, a evolução, como resultado da seleção natural, não implica nenhum planejamento prévio. Ela é apenas o resultado da maior ou menor adaptação de um grupo de indivíduos à ação imprevisível do ambiente sobre eles. Não é programada de antemão (como o Boeing 747 por engenheiros), mas também não é fruto do acaso (algo sem causa). É determinada pela interação dos dois fatores apontados pela teoria sintética: as características de cada indivíduo e as exigências do ambiente. Daí a conclusão: a explicação dos organismos vivos pela evolução resultante da seleção natural dispensa a existência de Deus. A ideia de uma inteligência que planeja de antemão os resultados da evolução e a orienta em determinada direção é ilusória.

\section{(b) Deus não é possível}

Do fato de Deus não ser necessário para explicar a evolução, não resulta que ele não exista. Por isso, Dawkins dá um novo passo na

${ }^{23}$ Cf. The God Delusion, p. 157s.

${ }^{24}$ O uso dos termos "finalístico" e "finalismo" nesse contexto é ambíguo. O que o cientista pode reconhecer - e de fato Dawkins reconhece - é a funcionalidade dos organismos. Por exemplo, o olho serve para ver, está organizado de tal maneira que pode exercer tal função, que não poderia exercer se não tivesse a estrutura que tem. Outra coisa é o princípio de finalidade, segundo o qual "todo agente age em vista de um fim", de modo que o fim, enquanto intencionado, precede a ação e, enquanto realizado, é o seu termo ou resultado. Trata-se de um princípio metafísico, do qual a ciência não pode valer-se em suas explicações, ou seja, não compete à ciência explicar finalisticamente a origem do olho, como o resultado de ações naturais orientadas previamente para a sua construção.

25 Dawkins cita, nesse contexto, a comparação atribuída ao astrônomo inglês Fred Hoyle (+2001): o surgimento da vida sem um determinismo prévio seria como se da passagem de um furacão por um depósito de lixo resultasse a montagem de um Boeing 747. 
sua argumentação. A existência de Deus é praticamente impossível, incompatível com a evolução ${ }^{26}$. Com efeito, Deus seria, por hipótese, aquela inteligência extraordinária (designer) postulada para explicar a organização admirável, extremamente improvável, dos seres vivos, como a existência de um Boeing 747, para ser compreendida e explicada, requer a existência dos engenheiros que o concebem e dirigem a sua construção.

Ora, se a organização complexa dos seres vivos é algo extremamente improvável (mas pode ser explicada pela seleção natural), a complexidade da inteligência que os teria planejado seria ainda maior e, portanto, mais improvável. Portanto, recorrer a essa hipótese não soluciona o problema, antes cria um novo problema ${ }^{27}$. Mas, não é só a maior improbabilidade da inteligência planejadora que constitui problema. O próprio recurso a essa explicação já é problemático, segundo Dawkins. Com efeito, se a inteligência divina explica a evolução, como se explicaria a inteligência divina, pergunta ele. $\mathrm{O}$ recurso à inteligência divina leva a retroceder indefinidamente na explicação e, portanto, a não explicar o que se pretende. Daí a nova conclusão: sendo a hipótese de uma inteligência divina planejadora dos organismos vivos imensamente improvável e mesmo incoerente, a existência de Deus é incompatível com a racionalidade científica.

\section{Discussão do criacionismo e do evolucionismo}

\subsection{Pressupostos para a solução do conflito entre evolução e criação}

Face ao criacionismo e ao evolucionismo, afirmamos a compatibilidade entre criação e evolução, desde que as noções de criação e evolução sejam corretamente entendidas e aplicadas. Para tanto, é necessário:

- partir de uma ideia válida de Deus e da criação divina;

- estabelecer a competência de cada tipo de racionalidade e saber: ciência, filosofia e teologia, em geral e a respeito do problema em pauta.

${ }_{26}$ Ele não conclui pela impossibilidade absoluta de Deus, porque reconhece, com razão, que a partir de dados científicos não é legítimo fazer afirmações absolutas (cf. ib., p. 51).

27 Podemos ilustrar a argumentação de Dawkins com o seguinte exemplo. Recorrer a Deus para explicar a improbabilidade do processo evolutivo seria como querer explicar, por exemplo, o erguimento dos enormes blocos de pedra (várias toneladas) das ruínas pré-históricas (2.500 a.C.) de Stonehenge pela ação de extraterrestres, cuja existência é ainda mais improvável. 


\subsubsection{Ideia de Deus}

Tanto o criacionismo como o evolucionismo referem-se ao Deus cristão, conforme é concebido tradicionalmente pelo monoteísmo ocidental. Ora, esse Deus é entendido como: uma realidade imaterial, infinitamente perfeita, distinta da realidade humano-mundana, que depende inteiramente desse princípio divino para ser e agir.

Evidentemente, nem todos os filósofos admitem a existência de Deus. Entretanto, o problema aqui abordado não é o da existência de Deus. Trata-se de saber se a ideia de um Deus criador do mundo, acima esboçada, é compatível com a ideia da evolução. Não interessa, portanto, discutir aqui os vários argumentos a favor e contra essa existência. $\mathrm{O}$ nosso objetivo é apenas verificar se a aceitação da evolução exclui a existência de Deus, como pensam tanto os evolucionistas, como Richard Dawkins, quanto os criacionistas radicais.

\subsubsection{Distinção entre conhecimento científico, filosófico e teológico}

\section{(a) Princípio hermenêutico geral}

As teorias científicas e as conclusões nelas fundadas não podem conflitar, em princípio, com as afirmações teológicas ou filosóficas, porque não se referem à mesma coisa sob o mesmo aspecto. A contradição implica que o objeto da afirmação e negação seja encarado sob a mesma perspectiva. Se ele é considerado sob diferentes pontos de vista não pode haver contradição entre o que dele se diz. Nesse sentido, a tradição escolástica distingue, na compreensão de algo, entre o objeto material, a coisa como tal, e o objeto formal, o aspecto sob o qual a coisa é considerada. A falta de clareza sobre essa distinção leva a equívocos e contradições aparentes, quando um termo, empregado em contextos diferentes, é entendido no mesmo significado.

Por exemplo: as duas proposições "O sol move-se no céu ao longo do dia" e "O sol não se move no céu ao longo do dia" são verdadeiras e não implicam contradição, desde que sejam feitas de diferentes perspectivas hermenêuticas, isto é, diferentes pontos de vista na interpretação da realidade. Com efeito, do ponto de vista da percepção imediata, a trajetória do sol do nascente ao poente é algo não só absolutamente certo, mas fundamental, enquanto regula os ritmos tanto da vida humana, como de toda a natureza na terra. Por outro lado, na perspectiva científica da teoria heliocêntrica, fundada em observações seguras, é também certo que o movimento do sol no céu é aparente, como consequência da rotação da terra em volta de seu eixo. Isto não significa que a explicação científica seja, em última análise, a única verdadeira e a percepção natural 
equivalha a uma aparência falsa. Pensar assim seria, de novo, ignorar a natureza hermenêutica da razão humana, que aborda a realidade necessariamente sob perspectivas parciais, que nem por isso deixam de revelar aspectos verdadeiros da realidade.

Em relação ao problema da evolução, as expressões "O mundo atual surgiu por evolução natural" e "O mundo atual surgiu por criação", podem ser ambas verdadeiras, se a primeira se refere a uma explicação científica das causas responsáveis pela atual configuração do mundo orgânico, e a segunda a uma compreensão filosófica ou teológica da realidade do mundo. Do mesmo modo, pode-se dizer contra o evolucionismo que Deus criou o mundo, entendendo que a existência e o funcionamento do mundo dependem em última análise de uma realidade perfeita e transcendente, isto é, Deus, como seu fundamento. Mas, ao mesmo tempo, deve-se afirmar que Deus não criou o mundo da maneira entendida pelo criacionismo, isto é, nos termos literais da narração bíblica.

\section{(b) Natureza do conhecimento teológico}

A teologia cristã, como ciência da fé, pretende compreender e interpretar racionalmente o conteúdo da revelação bíblica. Ela mostra que o objetivo da revelação bíblica não é oferecer uma explicação científica do mundo e da realidade em geral, mas manifestar o sentido da existência humana no seu todo e em vários aspectos fundamentais, bem como indicar o caminho que o ser-humano deve seguir para realizar o seu destino: ele não é autossuficiente, não é o centro da realidade, depende de um ser superior, fonte da vida, etc.

Por outro lado, a Bíblia exprime a sua mensagem numa linguagem religiosa de caráter narrativo e simbólico. Ela não emprega uma linguagem conceitual rigorosa, nem se apresenta como a exposição sistemática de uma doutrina. Portanto, por seu objetivo e por sua forma de expressão a revelação bíblica encontra-se em um plano radicalmente distinto do de qualquer teoria científica, de modo que não pode haver oposição entre elas.

\section{(c) Natureza do conhecimento filosófico}

Sem pretender aprofundar aqui o problema da natureza do conhecimento filosófico, podemos dizer que é próprio da filosofia na sua busca sobre o sentido último questionar radicalmente a realidade como um todo. Essa pergunta fundamental pode ter, em princípio, duas respostas: ou a realidade humano-mundana é autossuficiente, tem o seu fundamento em si mesma (imanência), ou ela não pode ser compreendida senão recorrendo a um fundamento distinto e superior (transcendência), que se identifica normalmente com o divino e na tradição filosófica do 
Ocidente com Deus, conforme definido acima. Portanto, a noção de criação, enquanto constitui uma resposta conceitual à questão sobre o sentido último da realidade é uma noção filosófica.

A filosofia distingue-se da teologia, enquanto pretende responder à questão do sentido último da existência, não refletindo racionalmente sobre o conteúdo de uma revelação divina, acolhida de antemão na fé, mas buscando tal resposta mediante a investigação da razão sem qualquer pressuposto religioso. Evidentemente, nem todos os filósofos admitem que a existência de Deus seja a resposta racional ao problema da realidade no seu todo. Entretanto, o nosso objetivo não é discutir tal problema. Trata-se apenas de verificar se a aceitação da evolução exclui a existência de Deus, como pensam tanto os evolucionistas, como Richard Dawkins, quanto os criacionistas radicais.

É preciso, contudo, ter presente que a nossa reflexão pressupõe a recusa do empirismo positivista, isto é, de qualquer posição filosófica que considere o método científico a única via de acesso ao real. Muitos cientistas, bem como certas correntes filosóficas, têm a tendência a assumir essa atitude. Entretanto, a própria questão sobre a natureza e os limites do método da ciência é uma questão filosófica. Evidentemente, para quem nega qualquer conhecimento trans-empírico, a ideia de Deus e da criação do mundo e muito mais a afirmação dessas realidades não tem o menor sentido. É nessa suposição, todavia, que iremos argumentar. Como já dissemos, não se trata de demonstrar a existência de Deus, mas de mostrar que a teoria sintética da evolução, não é incompatível com a existência de um ser infinitamente perfeito e criador, isto é, fundamento último de toda a realidade finita.

\section{(d) Natureza do conhecimento científico}

Antecipando a conclusão de uma breve análise da natureza e do método da ciência moderna, afirmamos que a ciência é metodologicamente agnóstica. O cientista pode naturalmente posicionar-se sobre a questão de Deus, mas a sua posição não pode logicamente basear-se em teorias científicas.

O método científico exclui a afirmação ou negação de Deus: as ciências positivas ou empíricas (física, química, biologia, sociologia, etc.), em um primeiro passo, observam os fenômenos naturais, isto é, aquilo que se manifesta na experiência humana, pressupondo a sua regularidade. Por exemplo, a partir de certas observações, mediante um processo indutivo, cuja validade é pressuposta, estabelece-se o ponto de fusão da água em condições normais de pressão, isto é, que a água no nível do mar, enquanto submetida à pressão de uma atmosfera, ferve a 100 graus. 
Em um segundo momento, a ciência procura explicar tais fenômenos, determinar as suas causas, os fatores que os suscitam. Esta explicação tem o caráter de uma hipótese, que é acolhida pela comunidade científica, na medida em que as suas consequências são confirmadas por certas observações específicas (testes ou experimentos), isto é, enquanto não seja falsificada ou desmentida por novas observações e, por conseguinte, substituída por outra hipótese que explique melhor o conjunto dos fenômenos em questão.

Em suma, a ciência explica fenômenos observáveis por outros fenômenos observáveis direta ou indiretamente. Ora, Deus, se existe, não é uma realidade intramundana, um fenômeno observável. É o que fica claro a partir da ideia de Deus, própria do cristianismo e das religiões monoteístas, bem como da tradição filosófica do Ocidente, conforme foi exposto acima. Sendo assim, a ciência, não pode recorrer a Deus para explicar os fenômenos, nem vice-versa, excluir a existência de Deus a partir da sua explicação dos fenômenos. Ela não pode falar de Deus, nem para afirmar, nem para negar a sua existência. Em outras palavras, Deus não é uma hipótese que possa ser verificada ou falsificada pela investigação científica. A questão da existência de Deus é estritamente filosófica. Daí se segue também que Deus, se existe, não está sujeito às leis naturais, que se aplicam aos fenômenos observáveis empiricamente ${ }^{28}$.

A ciência pode constatar que um fenômeno atualmente é cientificamente inexplicável. Mas, enquanto ciência, não pode tirar nenhuma conclusão sobre uma causa não-natural do fenômeno. Se Deus existe, pode ser que a causa deste fenômeno seja uma ação direta dele. Mas, isso não seria uma conclusão científica, mas filosófica.

A ciência não pode falar da causa do mundo como um todo: o método científico permite explicar a conexão entre os fenômenos observáveis, ou seja, a ciência explica as realidades intramundanas nas suas relações mútuas. Mas, não pode dizer nada sobre o mundo como um todo, porque as leis científicas se referem apenas às causas dos fenômenos intramundanos. Na expressão "o mundo como um todo", o todo não significa a soma das partes do mundo físico, nem simplesmente a sua extensão espacial, mas a realidade do mundo como tal, o que caracteriza radicalmente o seu modo de ser. Ora, essa não é uma abordagem cientifica,

${ }^{28}$ Portanto, não tem sentido conceber a inteligência divina criadora, como pretende Dawkins no argumento exposto acima, com o objetivo de descartar a sua possibilidade lógica, como resultado de um processo evolutivo da natureza, capaz de produzir uma realidade mais complexa do que os organismos a serem por ela explicados. Trata-se, na concepção teísta, de uma realidade transcendente e pré-existente ao mundo. 
mas filosófica. Portanto, embora a ciência suponha que tudo o que acontece tem uma causa e procure identificar a causa dos fenômenos, a pergunta "qual é a causa do mundo?" não é uma pergunta científica. Não pode ser respondida pela ciência, nem positiva, nem negativamente.

Por conseguinte, a ciência não pode recorrer a Deus como explicação da origem do universo. Por exemplo: se o universo tem efetivamente uma idade finita, como pretende certa interpretação da Teoria do Big-Bang, ou seja, se ele não existiu sempre, mas começou a existir, é necessário que tenha uma causa. Mas, essa afirmação não é uma conclusão científica. Todavia, as conclusões científicas podem levantar questões de caráter filosófico, das quais a filosofia não pode esquivar-se, mas deve procurar resolver, como veremos a seguir.

A ciência não pode oferecer uma base segura para a afirmação/negação de Deus: a ciência não oferece certezas inabaláveis. As suas teorias são sempre reformáveis. A verificação experimental de uma hipótese não é suficiente para confirmar que se trata da verdadeira explicação do fenômeno em questão. A hipótese científica é, inicialmente, uma conjectura sobre a causa de um fenômeno. A sua verificação torna-a apenas uma explicação possível, não necessária, do fato em questão. A razão é que se trata de uma comprovação indireta ${ }^{29}$. A hipótese, mesmo comprovada, pode ser sempre superada por uma nova explicação do fenômeno ou contrária à anterior ou mais detalhada e abrangente. De fato, isso acontece sistematicamente no campo das ciências. É próprio delas apresentar explicações cada vez mais adequadas, mas nunca definitivas ou absolutamente certas. Nisso consiste o progresso científico.

Portanto, qualquer argumento, mesmo de caráter filosófico, que apele para teorias científicas para demonstrar a existência de Deus não pode chegar a uma conclusão mais do que provável ${ }^{30}$. Por exemplo: se alguém afirma que o mundo atual começou a existir, tendo com base a Teoria do Big-Bang, ele deve ter uma causa, por exemplo, Deus. Mas, essa conclusão filosófica, a partir de uma premissa científica, não é segura, porque a afirmação científica sobre a duração limitada do mundo é apenas uma teoria provável, que por sua própria natureza pode ser um

29 Vejamos um exemplo vulgar: uma vasilha com um pouco d'água exposta ao ar livre no fim do dia está seca. Pode-se conjecturar que foi o calor do sol que provocou a evaporação da água e comprovar essa possibilidade, se de fato o sol brilhou naquele lugar e a quantidade de energia calorífica irradiada era suficiente para provocar a evaporação. Mas, a causa do desaparecimento da água pode ter sido outra, por exemplo, alguns animais que a beberam.

30 Dawkins o admite, como vimos. 
dia rejeitada ${ }^{31}$. Para provar com certeza que Deus é a causa do mundo é necessário partir da experiência de realidades incontestáveis, não dependentes de explicações científicas.

Conclusão a respeito da evolução biológica: a resposta ao dilema evolução versus criação é uma questão filosófica. Com efeito, a noção de criação, bem entendida, refere-se ao sentido último da realidade humanomundana, ou seja, se essa realidade no seu todo é autossuficiente, ou dependente na sua existência de uma realidade superior, isto é, de Deus como o seu criador. Essa pergunta, como vimos, não pode ser respondida pela ciência, que, por seu próprio método, limita-se a explicar os fenômenos particulares que ocorrem no mundo. A teologia, por sua vez, responde à pergunta sobre o sentido último, afirmando que toda a realidade humano-mundana é criada por Deus. Mas, a sua resposta baseia-se na fé e não em uma demonstração racional.

Pelo contrário, a questão da explicação do mecanismo da evolução é uma questão científica. Não compete à filosofia decidir se as teorias finalistas são mais bem fundadas cientificamente do que a teoria sintética. Tanto os seus adeptos quanto os seus adversários julgam, em geral, que a teoria do planejamento inteligente implica a existência de Deus. Já quanto à teoria sintética, uns e outros consideram que ela exclui essa existência. A posição que aqui defendemos é que em ambos os casos tanto uma posição como a outra labora em um mal-entendido epistemológico. De acordo com os princípios acima expostos, com base em uma teoria científica não se pode concluir nem a existência nem a inexistência de Deus. Afirmamos, portanto, que mesmo a teoria sintética, se for verdadeira, é plenamente conciliável com a ideia de um Deus criador.

\subsection{Avaliação do criacionismo à luz dos princípios expostos}

\section{(a) Quanto ao criacionismo em geral}

A negação criacionista da evolução em nome da criação divina baseiase, por um lado, em uma deformação antropomórfica da ideia cristã de Deus, ao tomar ao pé da letra as narrações bíblicas da criação; por outro,

31 Além disso, a própria teoria do Big-Bang afirma apenas que o universo conhecido teve um início há tantos bilhões de anos e está em contínua expansão, tendendo para um termo de expansão máxima, quando toda a energia propulsora se esgotará. O que sucederá então é de novo objeto de conjecturas dos astrônomos. Pode-se imaginar que, ao período de expansão, segue-se um período de retração até a concentração de toda a energia cósmica em um ponto mínimo, donde resultaria uma nova explosão (Big Bang) e expansão do universo, de modo que esse processo cíclico se repetiria infinitas vezes. Essa especulação mostra como a partir dos dados científicos não é possível extrair conclusões filosóficas seguras. 
na incompreensão da natureza da linguagem religiosa e do conhecimento teológico, ao postular da Bíblia uma explicação dos fenômenos empíricos, própria das ciências, considerando que Deus atua no mesmo nível das causas intramundanas.

Portanto, a teologia não é competente para dizer se houve ou não evolução e qual seria a sua explicação, isto é, o mecanismo do processo evolutivo. Essa é uma questão meramente científica.

Entretanto, compete à teologia cristã interpretar o sentido da revelação bíblica. Ora, ao contrário da interpretação fundamentalista, uma teologia que compreende o significado autêntico da noção cristã de criação, mostra que ela não se choca com a ideia científica de evolução. Com efeito, as narrações bíblicas sobre a criação do mundo (por exemplo, nos primeiros capítulos do Gênese) são de caráter simbólico. Não pretendem descrever fatos empíricos, como as ciências, nem fornecer uma explicação científica da origem do mundo.

Por outro lado, a afirmação teológica da existência de Deus e da criação do mundo por ele é baseada na fé. Portanto, a teologia permite rejeitar o criacionismo, mas não tem condições por si só de rejeitar racionalmente o evolucionismo, isto é, de provar que o mundo foi criado por Deus ou que a evolução não implica a negação de Deus.

\section{(b) Quanto ao planejamento inteligente}

Seria equivocado pretender provar a existência de Deus a partir da afirmação do caráter atualmente inexplicável para a ciência de determinado fenômeno, como faz a proposta do planejamento inteligente, diante da improbabilidade máxima da origem de certos organismos por forças meramente intramundanas. Com efeito, nada impede que o progresso científico venha a descobrir novos elementos que reduzam consideravelmente ou mesmo eliminem essa improbabilidade, afetando a probabilidade do argumento que nela se fundava. Na verdade, a demonstração filosófica, ao contrário da científica, não pode basear-se em meras probabilidades, que, como se sabe, não constituem garantia da verdade.

Mais radicalmente, enquanto postula a existência da inteligência criadora para resolver uma questão científica, qual seja a explicação do processo evolutivo, o planejamento inteligente desrespeita as características do método científico. Se os conhecimentos científicos atuais não permitirem explicar cabalmente o mecanismo da evolução, a conclusão científica correta será declarar que o fenômeno é hoje cientificamente inexplicável por causas imanentes à natureza e não apelar para uma causa transcendente como explicação científica dos fenômenos. Portanto, concluir a existência ou a inexistência de Deus, a 
partir do fenômeno da evolução, não seria uma afirmação científica, mas filosófica, ainda que epistemologicamente inconsistente.

\subsection{Avaliação do evolucionismo à luz dos princípios expostos}

Nossa avaliação do evolucionismo focalizará o argumento concebido por Dawkins para provar que a Teoria Sintética da Evolução exclui a existência de Deus. Como já dissemos, não pretendemos aqui demonstrar a existência de Deus, mas apenas que a teoria em questão não é incompatível com a existência de um ser infinitamente perfeito e criador, isto é, fundamento último de toda a realidade finita. Mostraremos que a argumentação proposta é falha por duas razões básicas: uma ideia equivocada do Deus cristão e uma incompreensão dos limites do método científico. Para tanto, abordaremos sucessivamente os dois passos de seu argumento.

\subsubsection{Quanto à não-necessidade de Deus para explicar a evolução biológica}

Dawkins entende a ação criadora como uma hipótese explicativa do processo evolutivo, sob a forma de uma intervenção de Deus no curso da natureza, que substitui a ação das causas naturais, semelhante à ação de um engenheiro que planeja e constrói um aparelho. Ora, essa hipótese é, para ele, desnecessária, já que a Teoria Sintética explica satisfatoriamente a evolução.

$\mathrm{Na}$ verdade, de acordo com a natureza do método científico, Deus, entendido como realidade imaterial e transcendente, não deve nem pode ser uma explicação científica da evolução. Por outro lado, se Deus existe, a sua ação criadora não pode ser concebida desta maneira, não pode ser equiparada à causalidade dos entes intramundanos.

Portanto, do fato de explicar-se cientificamente o processo evolutivo pela Teoria Sintética, não se segue que seja desnecessária uma reflexão filosófica sobre o sentido do mundo enquanto tal, que poderá ou não levar à afirmação da existência de Deus e da criação do mundo.

3.3.2 Quanto à impossibilidade da existência de Deus e da criação

Como vimos, Dawkins argumenta que atribuir a complexidade altamente improvável dos organismos resultantes da evolução a uma inteligência superior, que a tivesse dirigido finalisticamente, além de não ser necessário, já que a seleção natural explica o processo de complexificação, é uma postulação incoerente. Com efeito, essa inteligência teria uma complexidade ainda maior, cuja explicação seria mais improvável que o fenômeno a ser explicado e levaria a um processo de redução ao infinito, remetendo a fatores explicativos cada vez mais improváveis. 
Como se percebe facilmente, Dawkins incorre aqui no mesmo equívoco a respeito da ação de Deus que foi identificado há pouco. Entende a causalidade divina como a ação de um engenheiro que planeja a construção de um aparelho e o monta de acordo com o projeto preconcebido, atuando, portanto, no nível intramundano. O plano dessa inteligência superior seria o substituto da seleção natural como explicação do processo evolutivo ${ }^{32}$. Com isso, ele pretende mostrar a incoerência da tese do "planejamento inteligente" (intelligent design), que, de fato, propõe essa alternativa como explicação científica da evolução.

O argumento de Dawkins, sob esse aspecto, contém duas falhas graves. Em primeiro lugar, ele se baseia em uma ideia equivocada de Deus. Com efeito, considera sem sentido a ideia de uma inteligência criadora do mundo e responsável pela evolução biológica, porque ela deveria ser mais complexa e improvável do que os próprios organismos que deveria explicar e, enquanto mais complexa, emergir apenas em uma etapa tardia do processo evolutivo, como de fato acontece com a inteligência humana. Isso seria evidentemente absurdo.

Entretanto, tal concepção da inteligência divina como integrada na natureza e resultante de um processo de complexificação nada tem a ver com a ideia monoteísta de Deus, que ele pretende refutar, que corresponde a uma inteligência infinita e transcendente ao mundo em sua simplicidade imaterial e eterna. Portanto, a incoerência alegada por Dawkins não atinge a ideia autêntica de Deus e de sua ação criadora, mas valeria apenas de uma contrafação dessa ideia.

Por outro lado, ao mesmo tempo que dispensa uma causa da própria natureza, responsável única segundo ele da evolução biológica, Dawkins exige que a inteligência criadora seja causada, o que levaria efetivamente a um retrocesso sem fim na ordem das causas e que deixaria os fenômenos sem explicação. Ora, nessa argumentação ele comete uma dupla incoerência. Na verdade, a inteligência criadora, na concepção monoteísta, como realidade infinitamente perfeita, se existe, não pode ser causada, mas é necessária por si mesma. Com efeito, sendo por definição plenitude de perfeição, não pode ter uma causa que teria que ser mais perfeita que o efeito. Por outro lado, é a natureza que, enquanto

32 É o que Dawkins chama de a "Hipótese Deus" (the God Hypothesis), que ele define da seguinte maneira: "there exists a superhuman, supernatural intelligence who deliberately designed and created the universe and everything in it, including us". Ao que ele contrapõe a sua tese alternativa: "any creative intelligence, of sufficient complexity to design anything, comes into existence only as the end product of an extended process of gradual evolution. Creative intelligences, being evolved, necessary arrive late in the universe, and therefore cannot be responsible for designing it." (p. 31, itálicos do autor). 
imperfeita e em processo de aperfeiçoamento, ao contrário do que pensa Dawkins, precisa ser causada.

Portanto, a explicação científica da evolução pela Teoria Sintética não torna nem desnecessária nem impossível a existência de Deus, senão para quem só aceita como válido o conhecimento científico, o que é contraditório, como foi mostrado.

\section{Compatibilidade entre a ideia de criação e a teoria da evolução}

Trata-se agora de mostrar positivamente a congruência das ideias de criação e evolução. Nossa demonstração enfrentará, de início, dois aspectos básicos do problema da conciliação da concepção da evolução, segundo a teoria sintética, e a afirmação da criação divina, as questões da causa eficiente e do finalismo da evolução. Veremos que eles se contrapõem aos dois passos da argumentação de Dawkins acima apresentada.

\subsection{Criação e causa eficiente da evolução}

4.1.1 Conciliação entre a evolução biológica e a ideia da criação divina do mundo

\section{(a) Ideia filosófica de criação}

Segundo Dawkins, à luz da teoria neodarwinista, Deus não é necessário para explicar a evolução, que é perfeitamente explicada pela seleção natural, e, mais ainda, diante de tal teoria, a sua existência tornase absolutamente improvável, praticamente impossível. Ao contrário, a teoria do planejamento inteligente afirma que a evolução é inexplicável por causas puramente naturais, de modo que o fato da evolução, constatado cientificamente, implica necessariamente a afirmação de uma inteligência divina planejadora e executora do universo.

Trata-se em um caso como no outro de uma ideia equivocada de Deus e de sua ação criadora. Um e outra são colocados no mesmo nível das causas intramundanas, com as quais a ciência explica os fenômenos. A criação é entendida como uma intervenção de Deus no curso da natureza, intervenção, que é afirmada para suprir a inadequação das causas naturais, ou que é negada, porque as causas naturais explicam suficientemente os fenômenos, no caso, a evolução, o surgimento da vida, ou do ser humano.

Entretanto, se Deus existe, a sua ação criadora não pode ser concebida dessa maneira, não pode ser equiparada à causalidade dos entes 
intramundanos. Deus, se existe, é radicalmente distinto da realidade humano-mundana, como o infinitamente perfeito, plenitude de ser, se distingue do que é finito e contingente e que, portanto, depende na sua existência desse ser, Deus, que existe necessariamente. A sua ação criadora, ainda que livre, se identifica com o seu próprio ser. Nessa perspectiva, a criação significa a relação de dependência total da realidade humano-mundana para com Deus. É dele que ela recebe todo o seu ser.

Para esclarecer essa noção filosófica de criação, é necessário afastar diversos mal-entendidos. A causalidade divina não consiste na transformação ou modelagem de uma matéria pré-existente (como acontece com o artista, com o engenheiro, ou com as causas naturais no processo evolutivo). Trata-se dar a existência a uma nova realidade a partir do nada, ou seja, sem nenhum elemento pré-existente, a não ser o princípio ativo, que é a origem radical de tal realidade. Exclui-se também a ideia da criação como a transmissão de uma energia física da fonte ao receptor. Ao comunicar o ser à realidade finita, Deus não perde nada de sua plenitude infinita de ser. Isso pode ser explicado com a seguinte comparação. Quando alguém, por exemplo, um professor, comunica uma informação, todos os que recebem a informação dependem nisso do informante, que, entretanto, não perde nada ao comunicar o seu saber ${ }^{33}$.

A comparação, contudo, não é perfeita. De fato, a informação, uma vez comunicada, já não depende do informante para existir nos informados. Ao contrário, a realidade criada por Deus depende permanentemente dele para existir, porque tem nele o seu fundamento, como a lâmpada depende permanentemente da corrente elétrica e de sua fonte para manter-se acesa. Portanto, a criação não significa simplesmente uma ação de Deus no início do mundo, ação que talvez precise repetir-se em certos momentos para explicar determinados fenômenos especiais. Na verdade, mesmo se o mundo tivesse uma duração infinita, sem começo, nem fim, fosse eterno, como se diz vulgarmente, ele seria criado por Deus. Tal é a posição de Tomás de Aquino, já que a criação significa que o mundo não tem em si mesmo o seu fundamento, mas depende inteiramente de Deus para $\operatorname{ser}^{34}$.

${ }^{33}$ Por outro lado, como Deus é a plenitude de ser, a criação não constitui nem pode constituir um acréscimo a essa plenitude infinita de ser. Com a criação, não existe mais ser, mas apenas mais seres. A realidade do mundo não se soma à realidade de Deus. Ele se distingue do mundo como o infinitamente perfeito se distingue do que é finito e perfeito. Essa relação do mundo para com Deus pode ser entendida através da analogia entre o original e a cópia. Por exemplo, as cópias da Pietà de Michelangelo nada acrescentam à perfeição do original.

${ }^{34}$ É a tese do opúsculo "Sobre a eternidade do mundo contra os caluniadores" [De aeternitate mundi contra murmurantes], onde, embora admitindo, pela fé, que o mundo começou a existir, demonstra que ele poderia ter sido criado e não obstante existir desde sempre. 


\section{(b) Articulação entre a causalidade divina e a causalidade natural}

Por isso mesmo, porque a ação criadora de Deus é a comunicação total do ser da realidade criada, essa, juntamente com a dependência radical de Deus, goza de uma verdadeira autonomia no seu âmbito próprio. Ou seja, a ação criadora de Deus sustenta o ser e a ação da realidade criada, mas, em princípio, não interfere no nível da ação própria dos entes mundanos, pois, ao criá-los, confere-lhes as condições de realizar-se segundo a sua natureza. Nesse sentido, o curso do mundo é determinado pelos fatores nele existentes que atuam de acordo com a sua natureza e as suas leis imanentes.

Dizemos "em princípio", porque não se pode excluir a possibilidade de Deus, como criador, alterar eventualmente o modo de agir natural dos entes criados em virtude de um desígnio superior, desde que isso não implique uma contradição lógica. No entanto, a sabedoria do criador, na medida em que podemos desvendar o seu mistério, implica o respeito pela ordem por ele mesmo estabelecida no mundo criado. Portanto, o curso do mundo é determinado pelos fatores nele existentes, que atuam de acordo com a sua natureza e as suas leis imanentes. De fato, é mais de acordo com a sabedoria e a onipotência divinas dotar a sua criatura de recursos próprios para desenvolver-se e atingir os seus fins, do que precisar intervir para suprir a sua insuficiência ${ }^{35}$.

Essa relação Deus/mundo, sob o aspecto dinâmico, é expressa na linguagem tradicional da filosofia da seguinte maneira: a causa primeira (Deus) atua no mundo através das causas segundas (naturais). Nada se explica, em um plano radical e transcendente, próprio da filosofia, sem a causa primeira. Mas, tudo se explica no plano imediato dos fenômenos,

35 É o que exprime Tomás de Aquino, com uma frase lapidar: "Reduzir a perfeição das criaturas equivale a reduzir a perfeição do poder divino." Vale a pena citar o texto completo: "A perfeição do efeito demonstra a perfeição da causa. Ora, Deus é um agente perfeitíssimo. É necessário, pois, que as coisas por ele criadas recebam dele a perfeição. Portanto, rebaixar a perfeição das criaturas equivale a rebaixar a perfeição do poder divino. [...] Assim como é próprio do que é bom fazer o bem, assim é próprio do que é sumamente bom fazer algo da melhor maneira possível. Ora, Deus é sumamente bom [...]. Portanto, é próprio dele fazer tudo da melhor maneira possível. Ora, é melhor que o bem conferido a um seja comum a muitos do que seja próprio só dele. [...] Mas o bem de um torna-se comum a muitos se dele deriva para outros. Ora, isso não pode acontecer senão enquanto ele o difunde aos outros por sua própria ação. [...] Portanto, Deus de tal modo comunicou a sua bondade às coisas criadas que cada coisa possa transfundir nas outras aquilo que recebeu. Portanto, subtrair das coisas as próprias ações significa depreciar a bondade divina"; cf. Summa contra gentiles III c. 69, n. 15-16). Tomás argumenta, aqui, contra a opinião daqueles que recusam aos entes da natureza qualquer ação própria. Mas, os princípios invocados valem contra qualquer redução da capacidade de agir da criatura na ordem da natureza. 
acessível à ciência, pelas causas segundas, as causas naturais. A relação entre a causa primeira e as causas segundas pode ser ilustrada através da seguinte comparação. Suponhamos que alguém enche um copo de água. Em uma análise, que prescinde das discussões próprias da filosofia da mente, poderemos dizer que o ato de encher o copo resultou do movimento da mão determinado por uma série de processos fisiológicos: atividade dos neurônios, fibras nervosas, músculos, etc. Esses fenômenos acessíveis à observação empírica, própria das ciências, seriam comparados aqui à ação das causas segundas. Mas, pelo menos na compreensão do senso comum, todos esses processos foram determinados por um ato da vontade, que não é acessível à observação empírica. A vontade, nessa comparação, seria como a causa primeira, que efetua a sua decisão através da atuação de causas que se encontram em outro nível (causas segundas) ${ }^{36}$.

\section{(c) Conclusão}

Se Deus existe, a criação, como ação transcendente de Deus, é compatível com a evolução biológica, porque não compete com as causas naturais, mas sustenta-as no seu ser e agir. A sua ação criadora não pode nem deve ser entendida como uma interferência no curso da natureza, como a entende inadequadamente tanto o criacionismo, como o evolucionismo.

A Teoria Sintética da Evolução, à medida que for comprovada, explica satisfatoriamente, do ponto de vista científico, o surgimento sucessivo das espécies biológicas umas das outras, no curso do tempo, através do jogo das causas naturais. Mas, do ponto de vista filosófico, a própria ação das causas naturais deve ser explicada; na perspectiva teísta, essa explicação leva à afirmação de um princípio transcendente ao mundo.

Fica, assim, demonstrado, sob esse aspecto, que a evolução biológica e/ou cósmica e o fato de ser ela, eventualmente, explicada de maneira satisfatória por uma teoria científica, é plenamente compatível com a ideia de um mundo criado por Deus. E vice-versa, a afirmação da criação, pela fé ou pela razão, não exclui a evolução biológica e/ou cósmica, nem que ela possa ser explicada satisfatoriamente por uma teoria científica, sem recurso a uma intervenção direta de Deus.

36 A mesma comparação pode ser utilizada para explicar uma eventual intervenção direta da causa primeira no curso da natureza, possível, em princípio, como se disse. Esse caso seria comparável ao copo que se enche de água pela mera decisão da vontade, sem o movimento do braço ou qualquer outra causa perceptível. É uma das explicações dadas ao que se chama de milagre. 
Não estamos afirmando, porém, que a teoria sintética ou qualquer outra teoria explica satisfatoriamente a evolução. Essa é uma questão científica. Mas, mesmo na hipótese de ser comprovada e explicada cientificamente a evolução mais radical, sem necessidade da intervenção direta de Deus, esse fato não contradiria a afirmação da criação.

4.1.2 A evolução como processo de aperfeiçoamento dos seres orgânicos

(a) Problema da passagem evolutiva a um nível superior de realidade

A ciência constata que a evolução implica uma complexificação crescente dos elementos, desde a organização dos átomos e das moléculas até os organismos vivos unicelulares. Esses, por sua vez, dão origem ao longo do tempo a organismos pluricelulares, dentre os quais se destacam os animais, com uma maior unidade interior e maior capacidade de adaptação ao ambiente que outros seres vivos, mais tarde os vertebrados, os mamíferos, os primatas e, finalmente, o homem.

A ciência constata ainda que o organismo humano, em particular, o seu cérebro, apresenta um grau de complexidade superior ao de qualquer outra realidade mundana. Ela pode constatar também que, mediante o seu cérebro e outras prerrogativas morfológicas, o ser-humano é capaz de falar, pensar, tomar decisões, enquanto dotado de autoconsciência. Ela constata o fato, mas, por si mesma, não pode fazer um juízo de valor. Não lhe compete dizer que o ser humano é ontologicamente superior ou mais perfeito do que os outros organismos vivos. Esse julgamento é de caráter filosófico, embora possa ser feito por qualquer pessoa, que, enquanto dotada de inteligência, é capaz de refletir sobre o sentido e o valor dos fatos que observa.

Ora, segundo o princípio de causalidade o mais não pode provir do menos. Na perspectiva de uma filosofia naturalística, a consciência humana e toda a realidade cultural podem ser explicadas por fatores puramente orgânicos e naturais. Nesse caso, não existe na evolução o problema do mais provir do menos, porque toda a realidade está no mesmo nível da matéria organizada. Mas, para quem recusa reduzir os fenômenos mentais a mero efeito do funcionamento dos neurônios, sem consistência própria, a integração do ser-humano na natureza e no processo evolutivo (hominização), constitui um sério problema.

Em outras palavras, se a vida orgânica é uma realidade ontologicamente superior à realidade inorgânica e se o ser-humano é ontologicamente superior às demais espécies de viventes, por sua consciência, liberdade, 
etc., nos dois casos, o mais procederia do menos, o que contradiz a lógica da causalidade, a não ser que haja a intervenção de uma causa externa aos processos da natureza, que supra a sua deficiência. Nesse caso, a criação da vida e da consciência humana deveria aparentemente ser concebida como intervenção de Deus no curso da natureza, para assegurar certos passos do processo evolutivo, o que contradiria a Teoria Sintética.

\section{(b) Duas possíveis respostas}

O problema da hominização, ou seja, da transição biológica dos primatas superiores para a espécie Homo sapiens, mediante um longo processo evolutivo, pode ser resolvido filosoficamente por um aprofundamento da ideia da ação criativa de Deus, já exposta acima ${ }^{37}$. Essa resposta pode ser proposta em dois níveis de radicalidade.

A solução menos radical postula, efetivamente, uma intervenção singular de Deus no surgimento de cada indivíduo humano, enquanto inteligente e pessoal. Entretanto, Deus não intervém com uma intrusão no curso da natureza, infundindo a alma espiritual no novo indivíduo humano, como uma realidade estranha, em si mesma já completa e autossuficiente. Pelo contrário, a ação criadora de Deus insere-se no processo evolutivo, quando esse atinge o limite superior de suas possibilidades, proporcionando as condições orgânicas para a emergência da vida inteligente. Portanto, a intervenção especial de Deus não poderá ser percebida empiricamente. Nesse sentido, para o cientista, na medida em que considera o efeito no mesmo nível que a causa, as causas naturais continuam sendo a explicação do processo, de modo que a Teoria Sintética não é contradita pelo recurso à ação divina criadora.

Baseada também na natureza da relação entre a criatura e Deus estabelecida pela ação criadora, uma posição mais radical, proposta pelo teólogo católico K. Rahner, postula que não se requer uma intervenção divina especial para o surgimento do ser humano, dotado de alma espiritual. Na realidade, a ação criadora corresponde a um tipo transcendental de causalidade que não pode ser identificado simplesmente com as leis da causalidade entre entes intramundanos. Estes ao interagirem apenas alteram o modo de ser de uma realidade já existente, em função das

37 Essa é, como se disse, a explicação proposta por Karl Rahner. Cf. Karl Rawer und Karl Rahner, Weltall - Erde - Mensch, in: Franz Böckle - Franz Xaver Kaufmann Karl Rahner - Bernhard Welt, Christlicher Glaube in moderner Gesellschaft V.3, Freiburg - Basel Wien: Herder, 1981, p. 9-85 (aqui p. 53-65). Rahner resume nessa obra as considerações apresentadas originalmente in: Paul Overhage und Karl Rahner, Das Problem der Hominisation. Über den biologischen Ursprung des Menschen, Quaestiones Disputatae V. 12/13, Freiburg - Basel - Wien: Herder, 1961. 
propriedades que possuem, de modo que o resultado do influxo causal não pode ser ontologicamente superior à sua causa.

A causalidade divina, ao contrário, ao constituir o ente no seu ser, comunica-lhe tudo o que ele é e pode ser. Nesse sentido, "poder ser mais" é uma determinação ontológica do ente finito, enquanto, como criado, existe na dependência do ato divino criador. Esse "mais" é resultado da ação divina, mas não supõe uma intervenção específica de Deus, antes se funda na relação constitutiva e permanente do ente criado com o criador ${ }^{38}$. Por outro lado, como está implicada na própria relação de dependência da criatura para com o criador, essa determinação ontológica não corresponde a uma propriedade particular que a ciência possa identificar ao lado de outras no nível empírico da causalidade natural. Tampouco se trata de um determinante natural que influa diretamente no desenvolvimento dos processos físico-químicos ou biológicos.

A ação criadora contínua faz apenas com que, uma vez dadas as condições naturais de complexidade para um novo nível de ser, essa realidade ontologicamente superior surja de maneira espontânea a partir da potencialidade intrínseca do ente em questão, fundada na sua relação transcendental com o criador. Nesse sentido, também a emergência progressiva da consciência como uma realidade qualitativamente superior ao mundo material acontece quando o organismo se dispõe de tal maneira, especificamente enquanto sistema nervoso central, que se torna apto a sustentar o modo de ser próprio das atividades mentais. Esse "mais" nem resulta de uma intervenção direta do criador, nem contradiz as leis da causalidade intramundana, porque se funda na relação transcendental do ser finito com Deus ${ }^{39}$.

38Esse poder-ser-mais dos entes naturais já é admitido implicitamente pela ontologia tradicional em relação aos indivíduos vivos, que se desenvolvem a partir de suas potencialidades próprias, de modo que o indivíduo adulto (planta, ser humano) é mais, em muitos sentidos, do que no início de sua existência (semente, embrião). É verdade que se trata da ontogênese do organismo, dentro da mesma espécie biológica, e não da filogênese, como no caso da evolução, ou, em termos filosóficos, de um desenvolvimento acidental do mesmo indivíduo, e não da passagem a um tipo de substância ontologicamente, isto é, essencialmente superior.

39 Essa é uma explicação filosófica da origem do ser humano, na perspectiva da evolução, que parece condizer melhor com a autonomia relativa do criado. Entretanto, é compatível também com a teoria sintética da evolução, a explicação tradicional, que atribui diretamente a Deus a criação da alma humana, seja no processo evolutivo de hominização, isto é, da passagem de um antropóide a um ser humano, seja na geração de cada pessoa humana. Com efeito, nesse caso, todo o processo de dispor o organismo para o exercício das atividades mentais seria devido a causas naturais, identificadas pela ciência, mas a emergência de um ente, dotado de tal capacidade, exigiria a intervenção especial de Deus, que, entretanto, não interferiria no processo da natureza, mas apenas, de certo modo, o complementaria no nível da causalidade transcendental. 
Prolongando a comparação do movimento do braço pela vontade, podemos entender a proposta do seguinte modo. Os músculos do braço, sob o influxo da vontade, já têm, naturalmente, a potencialidade de esticálo todo, mas isso acontece paulatinamente à medida que as circunstâncias o exigem. Assim também a natureza, ainda que efetivamente em um dado momento não tenha atingido determinado grau de perfeição, em função de sua dependência permanente do influxo da causa primeira, é capaz de produzir por si mesma o ser mais que surge progressivamente no processo evolutivo. Esse ser mais se deve certamente, como toda a realidade mundana, à ação criadora de Deus, enquanto comunica à natureza o ser e o poder ser mais, embora essa virtualidade ontológica não se manifeste empiricamente senão quando atuada.

Concluindo, podemos dizer que em ambos os casos, isto é, com ou sem intervenção singular de Deus, a ideia de criação é compatível com a Teoria Sintética, porque a intervenção de Deus tem um caráter transcendental, de modo que não pode ser detectada no nível da observação empírica. O cientista observa a nova realidade, mais complexa, e só pode atribuí-la às causas naturais, as únicas que percebe empiricamente. Entretanto, não vê nisso contradição (o mais provindo do menos), porque a ciência, enquanto tal, não faz juízos de valor, afirmando que uma realidade é mais perfeita do que a outra. Pode apenas afirmar que ela é mais complexa na sua organização.

\subsection{Criação e finalismo do processo evolutivo}

(a) Problema da conciliação a imprevisibilidade dos resultados do processo evolutivo e o finalismo criador

O monoteísmo cristão afirma que Deus tem uma finalidade ao criar o universo. O ser humano, enquanto dotado de consciência e capaz de compreender o sentido das coisas, é o fim e o coroamento de toda a criação, destinado a participar livremente da plenitude de vida e felicidade divinas.

Ora, a Teoria Sintética da evolução afirma que não se pode detectar nenhum finalismo no processo evolutivo, isto é, os seus resultados sucessivos não podem ser previstos pelo exame científico das condições iniciais da natureza. Portanto, a ideia de criação, aparentemente, é incompatível com o neodarwinismo, aceito pela grande maioria da comunidade científica.

(b) Realização da finalidade divina da criação por procedimentos aleatórios

Certamente, um Deus, como o concebido pelo monoteísmo cristão, tem uma finalidade ao criar o universo. Ele o faz para manifestar a sua 
glória, ou seja, a grandeza de seu amor, comunicando o ser ao ser humano, criado à sua imagem e semelhança, para participar da plenitude de sua vida e felicidade. Entretanto, essa finalidade pode ser alcançada em princípio por dois caminhos.

No primeiro caso, o projeto criador seria realizado por um processo determinístico, imprimindo uma orientação finalística aos próprios processos naturais, de modo que os objetivos a serem atingidos possam ser detectados já nas suas origens. Nesse caso, a filogênese (origem e desenvolvimento da vida no seu conjunto) seria análoga à ontogênese (processo de desenvolvimento de um indivíduo vivo), na qual o resultado do processo está inscrito determinadamente no seu início, como pretende o Planejamento Inteligente. De fato, o desenvolvimento de um indivíduo orgânico está predeterminado no patrimônio genético de sua espécie desde a fusão dos gametas em uma nova célula: de tal semente resultará necessariamente uma mangueira e não uma goiabeira.

Entretanto, nada exige a priori que Deus realize esse plano criador mediante um processo determinístico. Em outras palavras: nada impede que Deus decida realizar os seus objetivos mediante a ação aleatória das causas naturais. Nesse caso, os resultados alcançados não podem ser previstos de antemão, do ponto de vista do observador intra-sistêmico, mas tão só explicados retroativamente, como pretende a Teoria Sintética. O conjunto das causas naturais produzirá efetivamente tais efeitos, isto é, o curso real da evolução, por mais improváveis que sejam, não, porém, de maneira determinística (como na ontogênese), mas de maneira aleatória. O termo aleatório não significa aqui "por acaso", no sentido de sem causa. Trata-se, porém, de um conjunto de causas cujo efeito não pode ser conhecido a priori com certeza, mas apenas determinado estatisticamente como uma probabilidade que, por menor que seja, pode acontecer.

Deus será, nesse caso, como um jogador que sabe que a partida terminará com sua vitória. Não se trata, contudo, de um jogo de xadrez, com lances calculados individualmente e articulados no seu conjunto para alcançar a vitória. A ação criadora é comparável, antes, a um jogo de dados, em que a vitória parece aleatória. Na verdade, porém, ela resulta da atuação de um conjunto de causas, cuja orientação para tal resultado, para o observador intra-sistêmico, não é previsível a priori, não podendo, portanto, ser detectada senão depois do que acontece ${ }^{40}$.

40 Ainda que dispusesse de todos os dados e medições a respeito dos fatores que influem no clima no dia 04 de fevereiro de 2010, seria impossível para o metereologista prever com certeza se choverá na Praça da Liberdade em Belo Horizonte às 14:00 horas do dia 04 de fevereiro do ano seguinte. Ao contrário da relação determinística entre a semente e a planta que dela nascerá, não há nenhuma lei que ordene os fatores climáticos, 
Assim, em um saco com 99 bolas negras e uma bola branca, pode acontecer que na primeira tentativa alguém retire a bola branca, apesar da improbabilidade. Também na loteria, por exemplo, um determinado bilhete será sorteado, como resultado dos processos mecânicos envolvidos. Não há, porém, uma lei que determine o resultado da ação do conjunto das causas em questão. Por isso, de antemão não se pode prever com certeza qual será esse bilhete, mas apenas a sua probabilidade maior ou menor de ser sorteado. Aplicado à explicação da evolução pela Teoria Sintética, o cálculo de probabilidades significa que o que é extremamente improvável não só poderá resultar a qualquer momento do jogo das causas em questão, mas também acontecerá por necessidade estatística, quando o número de tentativas repetidas, nesse caso ao longo de bilhões de anos, for inversamente proporcional ao grau de probabilidade do resultado.

No caso da evolução, segundo a Teoria Sintética, os resultados não podem ser previstos a priori, mas apenas explicados retroativamente. Porém, um Deus criador pode dispor o conjunto das causas naturais, de modo que o resultado por ele querido seja alcançado, embora aleatoriamente (por probabilidade), e não de maneira determinística. Nessa perspectiva, o mundo seria regido aparentemente por forças cegas da natureza, como pretende R. Dawkins, ao intitular um de seus livros "o relojoeiro cego", referindo-se ao poder construtivo da seleção natural. E é isso que pode concluir o cientista, como cientista, se for válida a teoria sintética da evolução. Entretanto, do ponto de vista do filósofo, essa visão científica do universo em evolução nem implica nem exclui a criação divina. Se ele, pela reflexão filosófica for capaz de demonstrar a existência de Deus, ou se a aceita simplesmente pela fé, esse Deus será necessariamente criador do universo e a sua criação é plenamente compatível também com um universo visto, a partir da mera investigação científica, como sem finalidade e sem sentido.

É importante que fique claro que não estamos propondo essa maneira de conceber a ação de Deus como verdadeira nem como a solução do enigma do universo. Com efeito, do ponto de vista filosófico, não podemos afirmar que a explicação do universo e de sua evolução pela teoria sintética seja preferível à teoria do planejamento inteligente ou vice-versa. Determinar qual dos dois caminhos (resultado determinado

como também os lances dos dados, de tal modo que se possa concluir algo sobre o seu resultado, além de meras probabilidades. Entretanto, a chuva ou a não chuva terá sido determinada por causas intramundanas definidas, embora o seu efeito seja imprevisível antecipadamente. Do mesmo modo, o observador intra-sistêmico que conhecesse todos os fatores em jogo no início do processo evolutivo não poderia prever o seu desenlace, embora ele seja uma consequência prevista por Deus da ação do conjunto de forças naturais do universo criado. 
nas causas, ou resultado imprevisível) foi efetivamente seguido pelo processo evolutivo é uma questão científica. Filosoficamente, pode-se, porém, afirmar que ambos, também a Teoria Sintética, são compatíveis com a ideia autêntica de criação. Na verdade, a noção de fim, como antecipação intencional no agente do resultado a ser obtido pela ação não é uma noção científica, mas filosófica. A ciência conhece apenas a noção de determinismo causal e de funcionalidade dos organismos (o olho humano é constituído de tal maneira que serve para ver).

Destarte, a finalidade da criação, a sua orientação para o surgimento da vida ou do ser humano, não pode ser afirmada como explicação científica da evolução (planejamento inteligente), mas apenas como consequência da ideia filosófica de criação. Com efeito, tal proposta equivaleria a introduzir a ação divina na sequência das causas intramundanas. Essa intervenção, alterando ou completando a ação das causas naturais, embora não seja impossível, seria excepcional, como também já ficou dito. Mas, em todo caso, a sua necessidade não pode ser postulada pela ciência, mas tão somente pela filosofia.

Portanto, nada impede que uma compreensão filosófica da realidade, reconhecendo o valor superior do ser humano, considere-o como o fim último da criação, fim esse alcançado pelo processo natural da evolução. Nessa perspectiva, todo o processo evolutivo, embora não necessariamente de maneira determinística, caminha em direção à consciência do ser humano, que pode formular a pergunta sobre o seu sentido. E é essa mesma capacidade de perguntar e compreender o sentido das coisas que, em última análise, dá sentido aos fantásticos mecanismos que ao longo de bilhões de anos através de um extraordinário acúmulo de improbabilidades e de aparentes desperdícios conduziram a esse resultado.

\section{Conclusão}

Haveria ainda muitos problemas específicos a tratar no terreno limítrofe entre a filosofia e as teorias científicas da evolução. O que foi dito é, porém, suficiente para deixar claro que o dilema evolução versus criação é falso. Não provamos que Deus existe nem que ele criou o universo. Tal não era o objetivo desse artigo. Mostramos apenas que a oposição entre as ideias de criação e evolução não tem um fundamento consistente, nem científico, nem filosófico ou teológico. A evolução não contradiz a ideia de criação, que, se Deus existe, deverá também ser afirmada.

Portanto, o evolucionismo, que nega a criação em nome da evolução, e o criacionismo, que nega a evolução em nome da criação, são posições ideológicas, resultantes de uma compreensão inadequada do que é 
a criação. Como se viu, bem entendida essa noção, seja em termos teológicos, seja em termos filosóficos, é plenamente compatível com a ideia de evolução, mesmo nas suas expressões científicas mais radicais.

Mas, se é tão clara a relação de compatibilidade entre criação e evolução, donde vêm - é imperioso perguntar - os contínuos conflitos entre os negadores da evolução ou da criação que se verificaram ao longo dos últimos 150 anos e se verificam ainda hoje? A resposta já foi dada por toda a exposição anterior. Trata-se sem dúvida de uma falta de clareza a respeito do método de cada um dos saberes em jogo e, por conseguinte, das próprias noções básicas envolvidas.

A teologia cristã contestou muitas vezes os resultados da investigação científica, especialmente a respeito da evolução, por uma falta de compreensão da verdadeira natureza da linguagem bíblica e do alcance das verdades da fé. Só aos poucos ao longo dos últimos séculos, a reflexão teológica foi tomando consciência do caráter próprio da interpretação religiosa da realidade, que se situa em um plano claramente distinto do da interpretação científica. Mesmo assim, muitos cristãos ainda não perceberam que a revelação do Antigo e do Novo Testamento não pretende dar uma explicação empírica da origem e do funcionamento do universo. Daí a recusa das teorias da evolução em nome de sua fé.

Por outro lado, é muito comum, não só entre cientistas, mas também de modo geral na mentalidade contemporânea, a ideia de que as ciências positivas constituem o único saber racional e autêntico. Só tem valor o conhecimento que é comprovado experimentalmente. Ora, essa afirmação não pode ser comprovada por nenhuma ciência. Não é uma proposição de caráter científico, mas filosófico, e, na verdade, insustentável.

Evidentemente, para quem a aceita, aderindo ao positivismo cientificista, a existência de Deus, já que não é objeto de comprovação experimental, não pode ser afirmada racionalmente. Mas, se Deus não existe, não tem sentido falar de criação. De fato, muita gente influenciada pela mentalidade positivista ou por outros preconceitos nega a priori a existência de Deus e a criação do mundo. A teoria da evolução, extrapolando os limites do método científico, torna-se então, na veste do evolucionismo, a forma concreta de uma visão integral da realidade, alternativa à ideia de um Deus criador. Todavia, a reflexão filosófica aprofundada sobre a natureza e o alcance dos vários tipos de saber, ao pôr em evidência a inconsistência tanto do evolucionismo como do criacionismo, mostrou claramente que a oposição evolução versus criação é um falso dilema. 